\title{
Reverse Transcription Loop-Mediated Isothermal Amplification of DNA for Detection of Potato virus $Y$
}

Xianzhou Nie, Potato Research Centre, Agriculture and Agri-Food Canada, P.O. Box 20280, 850 Lincoln Road, Fredericton, New Brunswick, E3B 4Z7 Canada

\begin{abstract}
Nie, X. 2005. Reverse transcription loop-mediated isothermal amplification of DNA for detection of Potato virus Y. Plant Dis. 89:605-610.

A reverse transcription loop-mediated isothermal amplification of DNA (RT-LAMP) for detection of Potato virus $Y$ (PVY) was developed. In this procedure, a set of four primers matching a total of six sequences of the coat protein $(\mathrm{CP})$ gene of PVY were designed in such a way that a loop could be formed and elongated during DNA amplification. Using PVY CP complementary DNA clones as templates, the LAMP reaction was optimized by adjusting the concentrations of $\mathrm{MgSO}_{4}$, dNTPs, and Bst DNA polymerase. The effects of fragment length of target DNA on LAMP also were investigated. Two-step and one-step RT-LAMPs were performed using RNA extracts of various PVY cultures, and the results were correlated with two-step reverse transcription polymerase chain reaction (RT-PCR) for detection of PVY. Further, the turbidity caused by precipitation of magnesium pyrophosphate formed in positive RT-LAMP reactions was used to measure the amplification by utilizing a time-saving spectrophotometric method. The one-step RT-LAMP-turbidity method gave results comparable with the two-step RT-PCR method for detection of PVY from potato leaf and tuber samples. Of the total 240 samples, 234 were diagnosed similarly by both methods.
\end{abstract}

Potato is the world's fourth most important crop following rice, wheat, and corn (1). To reduce the economic loss due to infection by various pathogenic microbes, including fungi, bacteria, and viruses, various management practices have been applied in potato production. Among them, potato seed certification for economically important pathogens such as Potato virus $Y$ (PVY) is one of the most notable measures (18).

Accurate and efficient detection of the pathogens is the backbone of the potato seed certification system (18). Several methodologies have been used to diagnose potato viruses, including PVY. These methods include bioassay (6), enzymelinked immunosorbent assay (ELISA; 2), and nucleic acid-based assays such as polymerase chain reaction (PCR; 5) and dot blot hybridization (4). Many important potato viruses consist of RNA genomes; therefore, complementary DNA (cDNA) synthesis by reverse transcription (RT) is required prior to detection of these viruses using PCR. The efficiency and accuracy of PCR and RT-PCR in diagnosis of viruses have led to their wide application in both research and diagnostic labs.

Corresponding author: X. Nie

E-mail: niex@agr.gc.ca

Accepted for publication 5 February 2005.

DOI: 10.1094/PD-89-0605

(C) 2005 The American Phytopathological Society
Recently, a method termed loopmediated isothermal amplification of DNA (LAMP) has been developed (13). Using four specially designed primers that include six short sequences matching the target DNA fragment, the DNA is amplified under isothermal conditions within a short period of time $(9,13)$. The reactions are easily monitored by detecting the turbidity caused by the formation of magnesium pyrophosphate (8). This method has been adopted for detection of various pathogens, including Mycobacterium spp (7), West Nile virus (14), and Japanese yam mosaic virus (JYMV; 3). It specifically detects the target microbes $(3,7,14)$. Here, an RT-LAMP procedure for detection of PVY is reported. The procedure is accurate and efficient with potential applications in diagnosis of the virus.

\section{MATERIALS AND METHODS}

PVY culture and potato materials. Several previously described PVY isolates were used, including $\mathrm{PVY}^{\mathrm{O}}-\mathrm{RB}, \mathrm{PVY}^{\mathrm{N}: \mathrm{O}}$ Mb112, PVY ${ }^{\text {NTN }_{-} \text {S150, }}$ PVY $^{N_{-J g} \text {, and }}$ PVY ${ }^{\text {NTN }}$-Tu660 $(11,12,15)$. The isolates were maintained in Nicotiana tabacum cv. Samsun plants in the greenhouse and checked every 3 to 4 months using multiplex competitive RT-PCR to ensure their purity and strain identity (11).

Tubers of Solanum tuberosum cv. Shepody were collected from the virus field plots at the Potato Research Centre. The tubers subsequently were planted in the greenhouse, and leaf samples (third leaf from bottom) were collected at the five-leaf stage.
PVY coat protein cDNA clones. PVY coat protein $(\mathrm{CP})$ cDNA clones containing the $\mathrm{CP}$ gene and $3^{\prime}$ untranslated region (3'UTR) of $\mathrm{PVY}^{\mathrm{N}: \mathrm{O}_{-}} \mathrm{L} 56$ and $\mathrm{PVY}^{\mathrm{N}: \mathrm{O}_{-}}$ Mb112 (12) were used as templates for development of the LAMP procedure for detection of PVY.

RNA isolation. Nucleic acid was isolated from leaves of potato and tobacco or tubers of potato as described previously (11). Briefly, $300 \mu \mathrm{l}$ of extraction buffer (0.1 M Tris- $\mathrm{HCl}, \mathrm{pH} 7.4,2.5 \mathrm{mM} \mathrm{MgCl}_{2}$, and $0.65 \% \mathrm{Na}_{2} \mathrm{SO}_{3}$ ) was combined with six drops (approximately $200 \mu \mathrm{l}$ ) of sap obtained from a Tuber Slicer (Electrowerk, Behcke and Co., Hannover, Germany). After incubating at $37^{\circ} \mathrm{C}$ for $10 \mathrm{~min}$, the mixture was extracted with $300 \mu$ l of phenol:chloroform:isoamyl alcohol (vol/vol/ vol, 25:24:1). The aqueous phase was collected after centrifugation $(12,000 \times g)$ at $4^{\circ} \mathrm{C}$ for $10 \mathrm{~min}$, and then $500 \mu \mathrm{l}$ of isopropanol and $50 \mu \mathrm{l}$ of $3 \mathrm{M}$ sodium acetate $(\mathrm{pH}$ 5.2) were added. After incubation at $-20^{\circ} \mathrm{C}$ overnight, the precipitate was collected by centrifugation $(12,000 \times g)$ at $4^{\circ} \mathrm{C}$ for 15 min. The resulting pellet was washed with $70 \%$ ethanol, dried under a vacuum, and dissolved in $200 \mu \mathrm{l}$ (tuber sample) or 1,000 $\mu \mathrm{l}$ (leaf sample) of sterile water.

RT-PCR. Nucleic acid extract $(2.5 \mu \mathrm{l})$ was incubated at $65^{\circ} \mathrm{C}$ for $8 \mathrm{~min}$ and chilled on ice for $3 \mathrm{~min}$, after which $7.5 \mu \mathrm{l}$ of RT mixture was added to provide a final concentration of $20 \mathrm{ng} / \mu \mathrm{l}$ of the reverse primer Y4A (Table 1), $50 \mathrm{mM}$ Tris- $\mathrm{HCl}$, $\mathrm{pH} 8.3,75 \mathrm{mM} \mathrm{KCl}, 10 \mathrm{mM}$ dithiothreitol (DTT), $2.5 \mathrm{mM} \mathrm{MgCl} 2,1.0 \mathrm{mM}$ of each dNTP (dATP, dTTP, dCTP, and dGTP), 5 $\mathrm{U}$ of RNasin Ribonuclease Inhibitor (Promega Corp., Madison, WI), and $100 \mathrm{U}$ of Moloney murine leukemia virus (MMLV) reverse transcriptase (Promega Corp.). Samples were incubated at $42^{\circ} \mathrm{C}$ for $1 \mathrm{~h}$ and $95^{\circ} \mathrm{C}$ for $2 \mathrm{~min}$. The resulting cDNA was used as template for PCR or two-step RT-LAMP.

Uniplex PCR with the primer pair Y3S and Y4A (Table 1) was performed on a Peltier Thermal Cycler (MJ Research, Watertown, MA) in a $25-\mu$ l volume containing $1 \times$ PCR buffer (10 mM Tris- $\mathrm{HCl}$, $\mathrm{pH}$ 8.3, $50 \mathrm{mM} \mathrm{KCl}), 1.5 \mathrm{mM} \mathrm{MgCl}_{2}, 0.2$ $\mathrm{mM}$ of each dNTP, $50 \mathrm{ng}$ of each Y3S and Y4A primers, $0.625 \mathrm{U}$ of AmpliTaq DNA polymerase (Applied Biosystems, Foster City, CA), and $2 \mu \mathrm{l}$ of cDNA or $20 \mathrm{ng}$ plasmid DNA. Samples were amplified for 30 cycles of $30 \mathrm{~s}$ at $92^{\circ} \mathrm{C}, 30 \mathrm{~s}$ at $57^{\circ} \mathrm{C}$, 
and $1 \mathrm{~min}$ at $72^{\circ} \mathrm{C}$. A final extension of 10 min at $72^{\circ} \mathrm{C}$ also was included. Amplified product $(8 \mu \mathrm{l})$ was electrophoresed in a $1.2 \%$ agarose gel containing ethidium bromide at $0.5 \mu \mathrm{g} / \mathrm{ml}$ and photographed under UV illumination with Alpha Innotech IS1000 imaging system (San Leandro, CA).

LAMP and RT-LAMP. LAMP and two-step RT-LAMP were carried out using plasmid DNA or cDNA as described above. cDNA or plasmid DNA $(2 \mu \mathrm{l}$ at 10 $\mathrm{ng} / \mu \mathrm{l}$ ) was incubated at $95^{\circ} \mathrm{C}$ for $5 \mathrm{~min}$ and chilled on ice, and $23 \mu \mathrm{l}$ of LAMP mixture was added to provide a final concentration of $20 \mathrm{mM}$ Tris- $\mathrm{HCl}, \mathrm{pH} 8.8,10 \mathrm{mM} \mathrm{KCl}$, $10 \mathrm{mM}\left(\mathrm{NH}_{4}\right)_{2} \mathrm{SO}_{4}, 0.1 \%$ Triton $\mathrm{X}-100$, $0.8 \mathrm{M}$ Betaine (Sigma-Aldrich, Oakville, Ontario, Canada), 2 to $10 \mathrm{mM} \mathrm{MgSO}_{4}, 0.2$ to $1.0 \mathrm{mM}$ each dNTP, $0.2 \mu \mathrm{M}$ each of one outer forward primer and one outer reverse primer, $0.8 \mu \mathrm{M}$ each of primer FIP and BIP (Table 1), and 1 to $12 \mathrm{U}$ of Bst DNA polymerase (New England Biolabs, Beverly, MA). The mixture was incubated at $65^{\circ} \mathrm{C}$ for $1 \mathrm{~h}$, followed by $80^{\circ} \mathrm{C}$ for $2 \mathrm{~min}$. LAMP products $(8 \mu \mathrm{l})$ were analyzed by electrophoresis as described above.

One-step RT-LAMP was performed using RNA as template. In a total volume of $25 \mu \mathrm{l}$, the reaction contained $2 \mu \mathrm{l}$ of RNA, $100 \mathrm{U}$ of M-MLV reverse transcriptase, or $1.25 \mathrm{U}$ of Avian myeloblastosis virus (AMV) reverse transcriptase (Promega Corp.) in addition to the components of regular LAMP using the primers F3, B3, BIP, and FIP. RNasin Ribonuclease Inhibitor $(5 \mathrm{U})$ and $5 \mathrm{mM}$ DTT also were included. If AMV reverse transcriptase was used, the mixture was incubated at $65^{\circ} \mathrm{C}$ for $1.5 \mathrm{~h}$ followed by $2 \mathrm{~min}$ at $80^{\circ} \mathrm{C}$. When M-MLV reverse transcriptase was used, the RNA was incubated at $65 \mathrm{C}$ for $5 \mathrm{~min}$ and chilled on ice. The mixture containing components of RT-LAMP was added to the denatured RNA solution. Thereafter, the solution was incubated at $42^{\circ} \mathrm{C}$ for $1 \mathrm{~h}$ and then $65^{\circ} \mathrm{C}$ for an additional hour, followed by $2 \mathrm{~min}$ at $80^{\circ} \mathrm{C}$. Products from the reaction were analyzed either by gel electrophoresis as described above or spectrophotometrically using a Microplate Reader (Molecular Devices, Sunnyvale, CA) at a wavelength of $405 \mathrm{~nm}$ or GeneQuant (Biochrom, Cambridge, UK) at a wavelength of $600 \mathrm{~nm}$.

\section{RESULTS}

Primer design. Four oligonucleotide primers (F3, B3, FIP, and BIP) that recognize a total of six sequences of the $\mathrm{CP}$ gene of PVY were designed (Table 1). F3 and B3 are outer primers whereas FIP and BIP are inner primers. Each of the two inner primers has two distinct adjacent sequences in opposite orientations. The first sequence (nucleotides 8,951 to 8,931) of FIP is in reverse orientation, whereas the second sequence (nucleotides 8,900 to 8,920 ) of the primer is in forward direction. In BIP, the forward sequence (nucleotides 9,004 to 9,024 ) is followed by the reverse sequence (nucleotides 9,056 to 9,036 ). Although only two outer primers are required in addition to the inner primers (13), to test the effects of fragment length of the target DNA on LAMP, four additional primers $(12,15)$ were selected (Table 1). Their relative locations in the virus genome are shown in Figure 1. The primers 912 (nucleotides 8,501 to 8,521 ), Y3S (nucleotides 8,721 to 8,740 ), and F3 (nucleotides 8,870 to 8,890) are in forward orientation; and the primers $\mathrm{Y} 3$ ' end ( $3^{\prime}$ end to nucleotide 9,688), Y4A (nucleotides 9,200 to 9,181), and B3 (nucleotides 9,078 to 9,059$)$ are in reverse direction. The primers recognize most strains and substrains of $\mathrm{PVY}$, including $\mathrm{PVY}^{\mathrm{O}}, \mathrm{PVY}^{\mathrm{N}}$, $\mathrm{PVY}^{\mathrm{NTN}}$, and $\mathrm{PVY} \mathrm{Y}^{\mathrm{N}: \mathrm{O}}$ based on the sequence alignments and BLAST analyses (data not shown).

Optimization of LAMP. Plasmid DNA containing the $3^{\prime}$ end fragment of PVY (nucleotide 8,501 to $3^{\prime}$ terminus, approximately $1.2 \mathrm{~kb}$ ) was used to test the efficacy of LAMP and to optimize the reaction. Initial conditions were adopted from Notomi et al. (13). The outer primers B3 and F3, together with the inner primers FIP and BIP, were used to optimize the LAMP reaction.
The effects of $\mathrm{Mg}^{2+}$, dNTP, and Bst DNA polymerase concentrations were tested (Fig. 2). An $\mathrm{MgSO}_{4}$ concentration of $2 \mathrm{mM}$ in the buffer for Bst DNA polymerase failed to produce any visible fragment of DNA. As the concentration of $\mathrm{MgSO}_{4}$ increased from 2 to $6 \mathrm{mM}$, the intensity of the ladder-like DNA amplification products increased, remained high up to $8 \mathrm{mM} \mathrm{MgSO}_{4}$, and decreased as it reached $10 \mathrm{mM}$ (Fig. 2A). Similar results were obtained when $\mathrm{MgCl}_{2}$ was used (data not shown).

The effects of dNTP concentration on PCR, especially on RT-PCR, have been widely studied (16). To test the effects of dNTP concentration on LAMP, 0.2 to 1.0 mM each dNTP (dATP, dTTP, dCTP, and dGTP) were used in the amplification reaction. At $0.2 \mathrm{mM}$, visible ladder-like DNA fragments were seen (Fig. 2B). As the dNTP concentration increased to $0.4 \mathrm{mM}$, the amount of amplified DNA also increased. The same level of amplification was observed at $0.6 \mathrm{mM}$ dNTP. However, at higher dNTP concentrations, the efficiency of LAMP decreased (Fig. 2B).

Under the optimized concentrations of $0.4 \mathrm{mM} \mathrm{dNTP}$ and $6 \mathrm{mM} \mathrm{MgSO}_{4}$, the efficiency of LAMP was dependent on the concentration of Bst DNA polymerase. When the enzyme concentration was $4 \mathrm{U}$ or less, poor amplification of DNA was observed (Fig. 2C). As the Bst DNA polymerase concentration increased from 4 to 8 $\mathrm{U}$, the amplification improved dramatically. Further increase of the enzyme concentration did not improve the amplification.

Taq DNA polymerase also was tested with various combinations of components as well as at different temperature regimes, and no amplification of DNA was observed under any of the conditions tested (data not shown).

Table 1. Oligonucleotide primers used for reverse transcription loop-mediated isothermal amplification of DNA (RT-LAMP) of coat protein gene of Potato virus $Y(\mathrm{PVY})$

\begin{tabular}{llll}
\hline Primer & \multicolumn{1}{c}{ Type } & \multicolumn{1}{c}{ Genome position $^{\mathbf{a}}$} & \multicolumn{1}{c}{ Sequence $\left(\mathbf{5}^{\prime} \mathbf{- \mathbf { 3 } ^ { \prime }}\right)$} \\
\hline F3 & Forward outer & $8,870-8,890$ & ATACGACATAGGAGAAACTGA \\
B3 & Reverse outer & $9,078-9,059$ & ACGCTTCTGCAACATCTGAG \\
FIP & Forward inner & $8,951-8,931$ and $8,900-8,920$ & GTTTGGCGAGGTTCCATTTC-TGTGATGAATGGGCTTATGGT \\
BIP & Reverse inner & $9,004-9,024$ and $9,056-9,036$ & TGAAACCAATCGTTGAGAATG-ATGTGCCATGATTTGCCTAAG \\
Y3S & Forward outer & $8,721-8,740$ & ACGTCCAAAATGAGAATGCC \\
Y4A & Reverse outer & $9,200-9,181$ & TGGTGTTCGTGATGTGACCT \\
912 & Forward outer & $8,501-8,521$ & AGCTTTCACTGAAATGATGGT \\
Y3'end & Reverse outer & $3^{\prime}$ end-9,688 & TTTTTTTTTGTCTCCTGATTGAAG \\
\hline
\end{tabular}

a Nucleotide position refers to the nucleotide sequence of PVY ${ }^{\mathrm{N}: \mathrm{O}}-\mathrm{Mb} 112$ (accession number AY745491). 
Effects of fragment length on LAMP. Five combinations of different outer primers were tested to explore the effects of size of target PVY cDNA on the efficiency of LAMP. Based on the primer location in the genome, primers $\mathrm{F} 3$ and $\mathrm{B} 3$ produced a fragment of $209 \mathrm{bp}, \mathrm{Y} 3 \mathrm{~S}$ and Y4A gave a 480-bp fragment, 912 and Y4A produced a 700-bp fragment, Y3S and Y3'end produced a 977-bp fragment, and 912 and Y3'end yielded a 1,197-bp fragment. Primers first were tested by PCR and the predicted fragment lengths were confirmed by agarose gel electrophoresis (data not shown). When LAMP was performed, all primer combinations resulted in ladder-like DNA in the positive samples (Fig. 3), indicating successful amplification of the target PVY cDNA. However, the intensity of the amplification products appeared to be greater in combinations where the fragments of target cDNA ranged from 209 to $977 \mathrm{bp}$, and slightly weaker when the fragment reached a size of $1,197 \mathrm{bp}$. The data from our experiments indicate that, within the range of 209 to $977 \mathrm{bp}$, fragment length of target cDNA has little effect on LAMP.

Two-step RT-LAMP detection of PVY. Total RNA isolated from tobacco leaves was reverse transcribed using M-MLV reverse transcriptase. The resulting cDNA then was used as template for PCR and LAMP amplification of the target DNA. A PVY-specific fragment (480 bp) was detected from all PVY-positive samples as well as the positive plasmid controls by PCR (Fig. 4). No PVY band was observed in healthy samples or water controls, although DNA in the form of smears in the gel was observed in the first two healthy samples (Fig. 4A). When the same set of samples was tested by LAMP, all positive samples exhibited ladder-like DNA fragments, whereas no fragments were produced from healthy samples or water controls (Fig. 4B). Similar to products generated by PCR, weak DNA smears were present in the first two healthy samples (Fig. 4B), which may be due to an excess amount of RNA used in the reaction. The results indicate that two-step RTLAMP detected all PVY isolates tested regardless of strain, which correlates with the two-step RT-PCR results.

One-step RT-LAMP detection of PVY. To further increase the efficiency of LAMP-based detection of PVY, one-step RT-LAMP was explored. Both M-MLV reverse transcriptase and AMV reverse transcriptase were tested. When M-MLV reverse transcriptase was used, total RNA was denatured prior to addition of the RTLAMP reaction mix. Because the optimal temperature for M-MLV reverse transcriptase is approximately $42^{\circ} \mathrm{C}$, the resulting solution was incubated at this temperature for the RT reaction and then raised to $65^{\circ} \mathrm{C}$ for LAMP. When AMV reverse transcriptase was used, total RNA was added di- rectly to the RT-LAMP reaction mix and incubated at $65^{\circ} \mathrm{C}$ for both RT and LAMP. All PVY-positive samples exhibited ladder-like DNA fragments when the AMV reverse transcriptase was used (Fig. 5B). Less efficient amplification of DNA in the PVY-positive samples occurred using $\mathrm{M}$ MLV reverse transcriptase (Fig. 5A). In either case, no visible amplification of DNA was observed in healthy samples and water controls (Fig. 5A and B), demonstrating the high specificity of RT-LAMP for detection of the virus. The results also concur with the results of two-step RTLAMP and two-step RT-PCR.

Detection of positive reactions. Insoluble magnesium pyrophosphate is the byproduct of LAMP (8), and the compound has been used to measure and monitor the reaction $(3,8,14)$. A positive reaction was accompanied by a visible precipitate, presumably due to the formation of magnesium pyrophosphate during the reaction (Fig. 5C; Table 2). The turbidity also can be measured spectrophotometrically (8). Absorbance readings at $405 \mathrm{~nm}\left(A_{405}\right)$ and

A

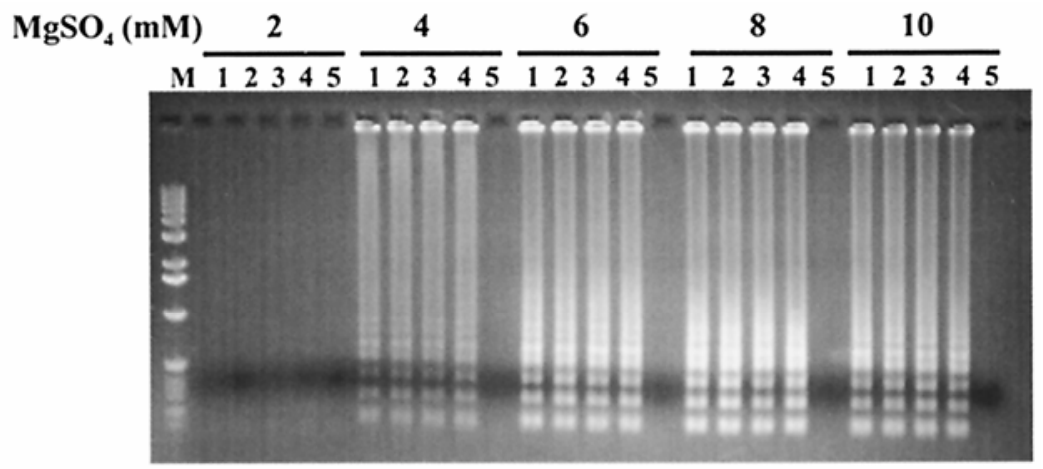

B
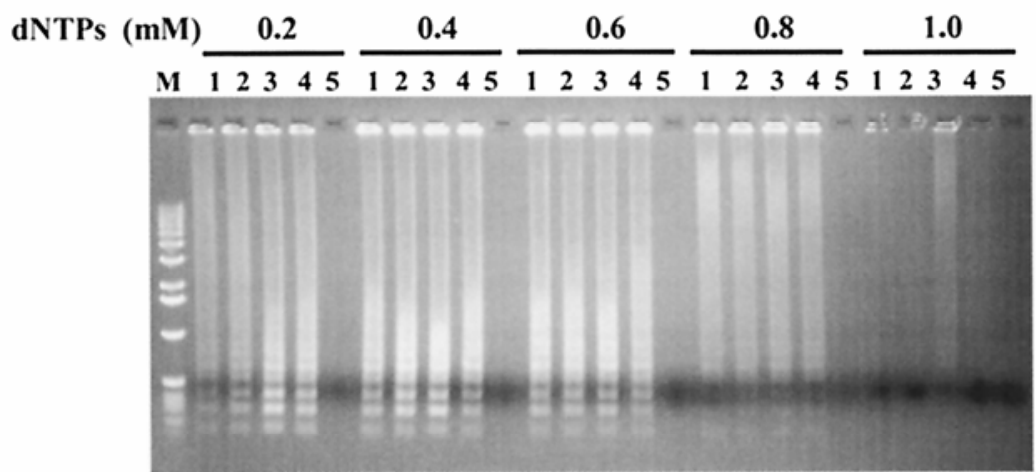

C Bst (U)
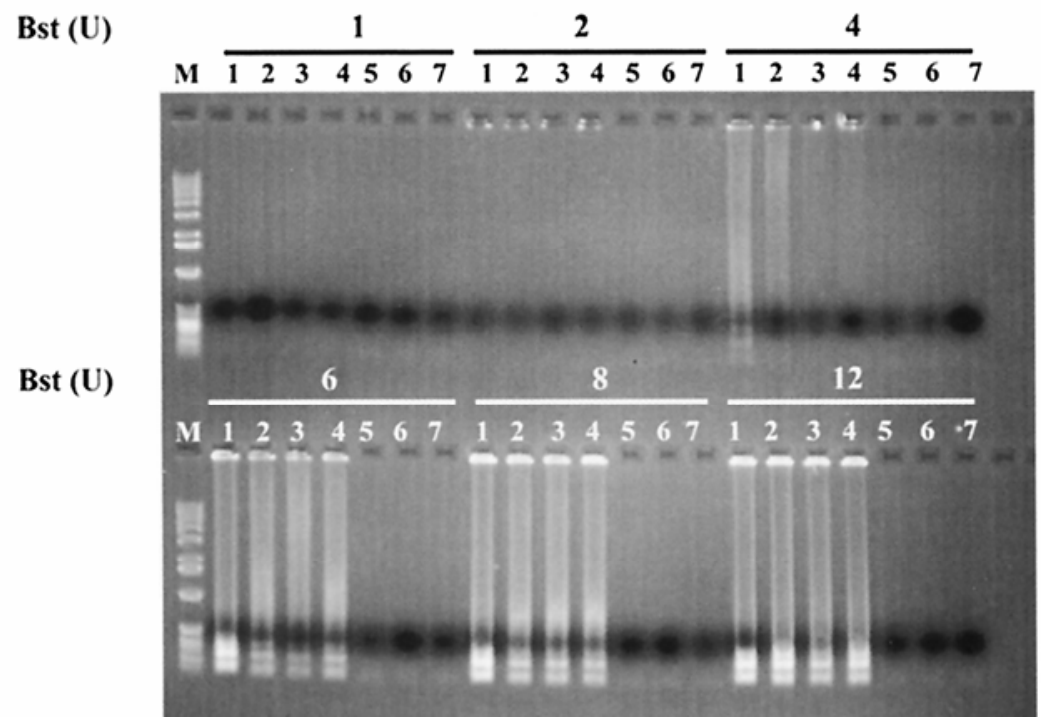

Fig. 2. Optimization of loop-mediated isothermal amplification of DNA (LAMP) for detection of Potato virus $Y(\mathrm{PVY})$. A, Effects of $\mathrm{Mg}^{2+}$ concentration on LAMP using $0.4 \mathrm{mM}$ each dNTP and $8 \mathrm{U}$ of Bst DNA polymerase. B, Effects of dNTP concentration on LAMP using $6 \mathrm{mM} \mathrm{MgSO}_{4}$ and $8 \mathrm{U}$ of Bst DNA polymerase. C, Effects of Bst DNA polymerase concentration on LAMP using $6 \mathrm{mM} \mathrm{MgSO}_{4}$ and $0.4 \mathrm{mM}$ each dNTP. Lane M, 1-kb DNA ladder; lanes 1-4, plasmid containing the coat protein gene and 3' untranslated region of $\mathrm{PVY}^{\mathrm{N}: \mathrm{O}}$ isolates; lane 5, plasmid without PVY insert; lanes 6-7 in C, negative controls (water). 
$600 \mathrm{~nm}\left(A_{600}\right)$ obtained from a microplate reader and a spectrophotometer (Gene Quant), respectively, were higher in samples showing cloudiness than those that were clear (Table 2). Agarose gel electrophoresis-based detection confirmed the positive amplification of DNA in the samples resulting in higher absorbance readings and visible turbidity (Table 2). The RT-LAMP also correlated with RT-PCR results with the same samples.

Potato tubers $(n=120)$ collected from the virus-research field plots were tested for PVY using both RT-PCR and one-step RT-LAMP-turbidity analysis (Table 3 ). In all, 83 samples were positive by the RTLAMP assay and 84 by RT-PCR test. Leaves of daughter plants of the tubers also were tested for PVY by both methods.
Of the 120 leaf samples, 91 were positive by RT-LAMP assay and 89 were positive by RT-PCR test. Both methods detected more PVY-positive samples in leaves than in tubers. When the two methods were compared, over $98 \%$ (118/120) of individual leaf tests were consistent between the two assays. Of 120 individual tuber tests between the two procedures, 116 were in agreement. Correlation of RT-LAMP results with RT-PCR results was $97.5 \%$.

\section{DISCUSSION}

LAMP is a relatively new technique that exhibits good potential for diagnosis of various pathogens $(3,14)$. In this study, a LAMP-based assay for detection of PVY was developed. Using PVY CP cDNA clones as templates, the efficacy of primers

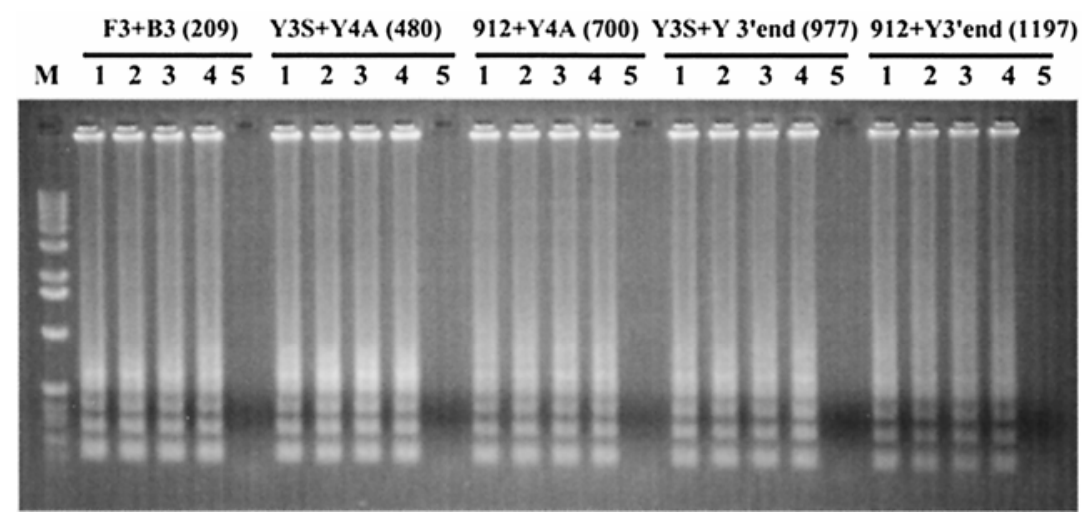

Fig. 3. Effects of fragment length of target complementary DNA (cDNA) on loop-mediated isothermal amplification of DNA for detection of Potato virus $Y$ (PVY). Outer primer combination and fragment length of target cDNA (in base pairs) of each primer set are shown above the photo. Optimized conditions that included $6 \mathrm{mM} \mathrm{MgSO}$, $0.4 \mathrm{mM}$ each dNTP, and $8 \mathrm{U}$ of Bst DNA polymerase were used. Lane M, 1-kb DNA ladder; lanes 1-4, plasmid containing the coat protein gene and 3 ' untranslated region of $\mathrm{PVY}^{\mathrm{N}: \mathrm{O}}$ isolates; lane 5, plasmid without PVY insert.

A

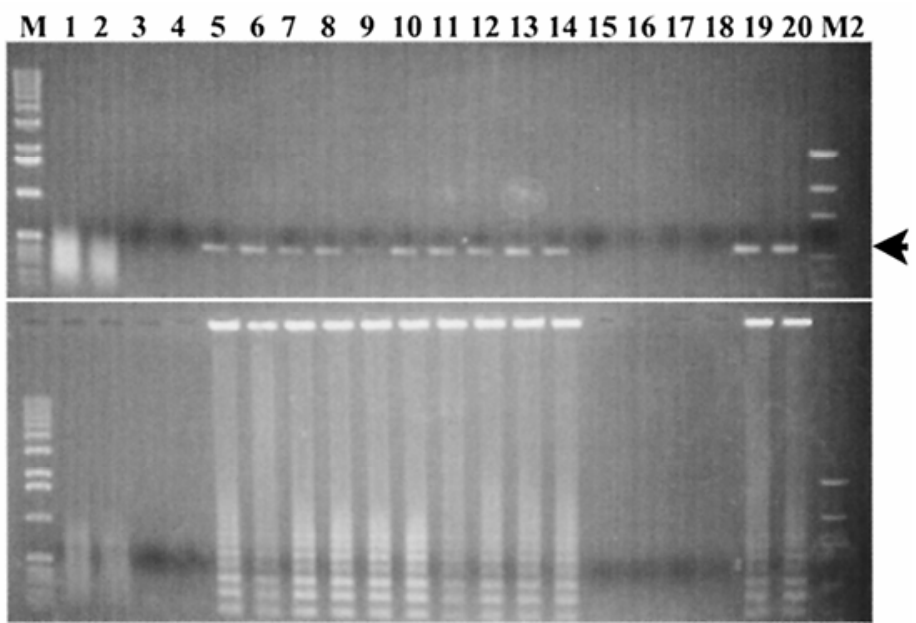

Fig. 4. Reverse transcription polymerase chain reaction (RT-PCR) and two-step reverse transcription loop-mediated isothermal amplification of DNA (RT-LAMP) for detection of Potato virus Y (PVY). A, RT-PCR detection of PVY. Arrow indicates the amplified PVY fragment (480 bp) resulting from primers Y3S and Y4A. B, RT-LAMP detection of PVY. Outer primers were Y3S and Y4A. RNA isolated from tobacco plants (healthy or inoculated with various PVY isolates) was used as template for RT, and the resulting complementary DNA used for PCR and LAMP. Lane M, 1-kb DNA ladder; lanes 14, healthy plants; lanes 5-6, PVY ${ }_{-R B}$; lanes 7-8, PVY ${ }^{\mathrm{N}: \mathrm{O}}-\mathrm{Mb} 112$; lanes 9-10, PVYNTN-S150; lanes 11-12, PVY ${ }^{\mathrm{N}}$ Jg; lanes 13-14, PVY ${ }^{\mathrm{NTN}}-\mathrm{Tu} 660$; lanes 15-18, negative controls (water); lanes 19-20, plasmid containing the coat protein gene and $3^{\prime}$ untranslated region of PVY ${ }^{\mathrm{N}: \mathrm{O}}$ isolates; lane M2, lowmass DNA ladder. as well as the reaction optimization was tested. As shown elsewhere $(3,13,14)$, appropriate primers are critical for successful LAMP. Six oligonucleotide sequences assure the specificity of the reaction, and the structures of the primers ensure loop initiation and elongation of the targeted DNA (13). Other parameters, such as $\mathrm{Mg}^{2+}$, dNTP, and DNA polymerase concentrations, also play a significant role in LAMP, as suggested elsewhere $(3,13)$. At least $4 \mathrm{mM} \mathrm{Mg}^{2+}$ was needed for a noticeable reaction, whereas 6 to $8 \mathrm{mM}$ resulted in an optimal reaction. Although both $\mathrm{MgCl}_{2}$ and $\mathrm{MgSO}_{4}$ worked equally well (data not shown), $\mathrm{MgSO}_{4}$ was chosen for consistency with the recommended buffer for Bst DNA polymerase. Under the optimal $\mathrm{MgSO}_{4}$ concentration, 0.4 to 0.6 $\mathrm{mM}$ each dNTP resulted in the highest amplification of DNA. Of the DNA polymerases (Taq and Bst) tested, Bst DNA polymerase produced the best results, with a minimum of $6 \mathrm{U}$ required for amplification of the target DNA under the optimal $\mathrm{MgSO}_{4}$ and dNTP concentrations. Although it has been reported that size of the target DNA affects the efficiency of LAMP (13), the results in this study reveal that fragment length of the target PVY cDNA had little effect on the reaction under optimal conditions. These results indicate that outer primers can be located several hundred bases to approximately $1 \mathrm{~kb}$ apart in the DNA of interest, thus giving more flexibility in selecting suitable primers for LAMP.

Complementary DNA synthesis by reverse transcription is required prior to detection of PVY using PCR and LAMP. Using the same set of cDNA, RT-PCR and two-step RT-LAMP produced the same results, confirming the specificity of RTLAMP. One-step RT-LAMP with AMV reverse transcriptase, in which the reverse transcription and LAMP were conducted in the same solution at $65^{\circ} \mathrm{C}$, exhibited high specificity and efficiency. The production of magnesium pyrophosphate during the reaction resulted in visible turbidity of the solution (8). By detecting turbidity, RTLAMP can be monitored visually and spectrophotometrically using a microplate reader, which can save significant time and cost in analyzing data. When applied to potato tuber and leaf samples, the one-step RT-LAMP-turbidity assay produced results that were comparable with the RT-PCR assay for detection of PVY, thus confirming the efficacy of RT-LAMP for diagnosis of the virus.

The relative simplicity in reaction setup and product detection and the high efficiency are apparent advantages of the onestep RT-LAMP-turbidity assay over the two-step RT-PCR method. In addition, the isothermal conditions required by RTLAMP could be met easily using a water bath, whereas the rapid and accurate temperature change required by RT-PCR needs 
A

$\begin{array}{lllllllllllllllllll}M & 1 & 2 & 3 & 4 & 5 & 6 & 7 & 8 & 9 & 10 & 11 & 12 & 13 & 14 & 15 & 16 & 17 & 18\end{array}$

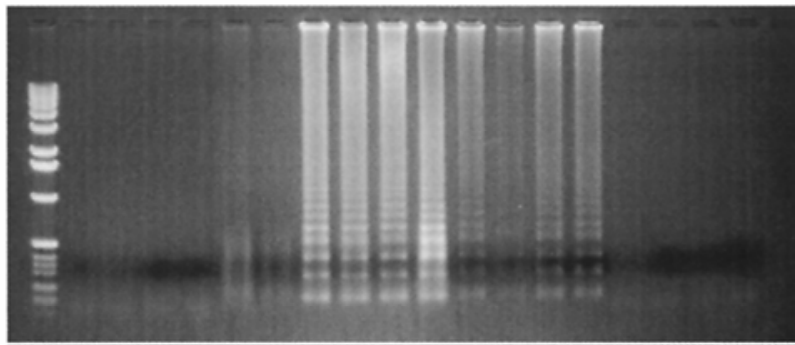

B
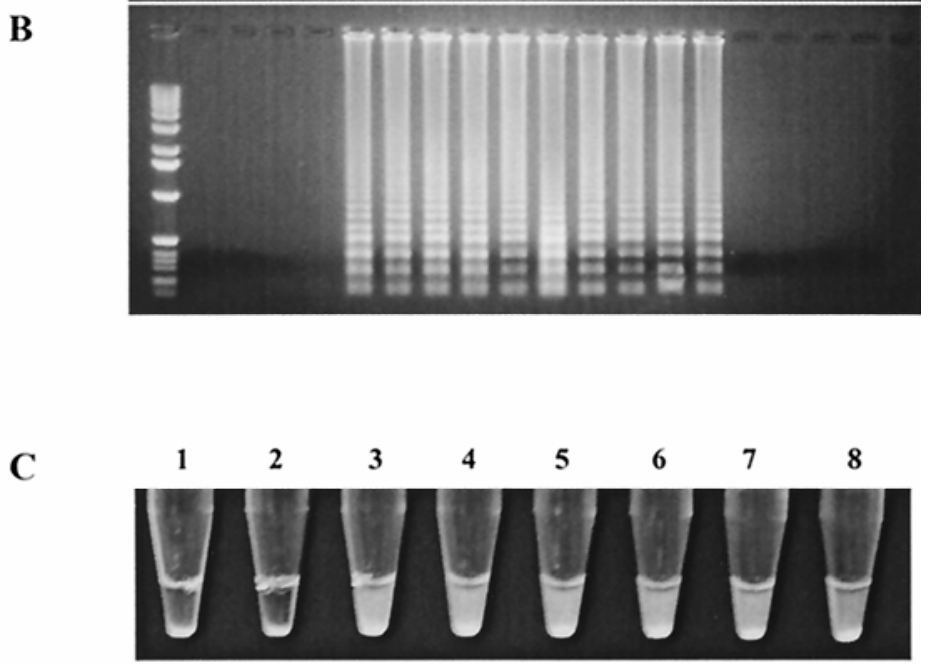

Fig. 5. One-step reverse transcription loop-mediated isothermal amplification of DNA (RT-LAMP) for detection of Potato virus $Y$ (PVY). A, Moloney murine leukemia virus reverse transcriptase-mediated one-step RT-LAMP. B, Avian myeloblastosis virus reverse transcriptase-mediated one-step RT-LAMP. C, Visual observation of RT-LAMP solution after the reaction. RNA isolated from tobacco plants (healthy or inoculated with various PVY isolates) was used as template for the reactions. A and $\mathbf{B}$, Lane M, 1-kb DNA ladder; lanes 1-4, healthy plants; lanes 5-6, PVYO-RB; lanes 7-8, PVY ${ }^{\mathrm{N}: \mathrm{O}_{-}}$ Mb112; lanes 9-10, PVY ${ }^{\mathrm{NTN}}$-Sl50; lanes 11-12, PVYN -Jg; lanes 13-14, PVY $Y^{\mathrm{NTN}}$-Tu660; lanes 15-18, negative controls (water). C, Tube 1, negative control (water); tube 2, healthy plant; tubes 3-4, $\mathrm{PVY}_{-}$ RB; tube 5, PVY ${ }^{\mathrm{N}: \mathrm{O}_{-}}-\mathrm{Mb} 112$; tube 6, $\mathrm{PVY}^{\mathrm{NTN}_{-}}-\mathrm{Sl} 50$; tube 7, $\mathrm{PVY}^{\mathrm{N}}-\mathrm{Jg}$; tube 8, PVY ${ }^{\mathrm{NTN}}-\mathrm{Tu} 660$.

Table 2. Turbidity and gel electrophoresis-based detection of positive reverse transcription loopmediated isothermal amplification of DNA (RT-LAMP) compared with reverse transcription polymerase chain reaction (RT-PCR) for detection of Potato virus $Y$ (PVY)

\begin{tabular}{|c|c|c|c|c|c|}
\hline \multirow[b]{2}{*}{ Sample } & \multicolumn{4}{|c|}{ RT-LAMP $^{\mathbf{a}}$} & \multirow{2}{*}{$\begin{array}{c}\text { RT-PCR } \\
\text { AGE } \\
\end{array}$} \\
\hline & Visual & $A_{405}$ & $A_{600}$ & AGE & \\
\hline Water & Clear & $0.002 \pm 0.002$ & $0.003 \pm 0.002$ & - & - \\
\hline Healthy & Clear & $0.001 \pm 0.002$ & $0.019 \pm 0.018$ & - & - \\
\hline $\mathrm{PVY}^{\mathrm{O}}-\mathrm{RB}$ & Cloudy & $0.041 \pm 0.009$ & $0.217 \pm 0.028$ & + & + \\
\hline $\mathrm{PVYO}^{\mathrm{O}}-\mathrm{RB}$ & Cloudy & $0.044 \pm 0.001$ & $0.238 \pm 0.037$ & + & + \\
\hline $\mathrm{PVY}^{\mathrm{N}: \mathrm{O}}-\mathrm{Mb} 112$ & Cloudy & $0.054 \pm 0.001$ & $0.313 \pm 0.052$ & + & + \\
\hline $\mathrm{PVY}^{\mathrm{NTN}}-\mathrm{S} 150$ & Cloudy & $0.052 \pm 0.001$ & $0.251 \pm 0.025$ & + & + \\
\hline PVY $^{N_{-} J g}$ & Cloudy & $0.050 \pm 0.006$ & $0.311 \pm 0.097$ & + & + \\
\hline PVY ${ }^{\text {NTN_Tu660 }}$ & Cloudy & $0.052 \pm 0.006$ & $0.287 \pm 0.076$ & + & + \\
\hline
\end{tabular}

a One-step RT-LAMP using primers F3, B3, BIP, and FIP. Absorbance readings at $405 \mathrm{~nm}\left(A_{405}\right)$ and $600 \mathrm{~nm}\left(A_{600}\right)$ were obtained from Microplate Reader and GeneQunt, respectively. AGE = agarose gel electrophoresis. Absorbance data shown were means \pm standard deviations from one assay with three replicates. Experiments were repeated three times.

Table 3. Reverse transcription loop-mediated isothermal amplification of DNA (RT-LAMP) and reverse transcription polymerase chain reaction (RT-PCR) for detection of Potato virus $Y$ from potato samples

\begin{tabular}{lcrrc}
\hline Sample & Quantity & \multicolumn{1}{c}{ RT-LAMPa $^{\mathbf{c}}$} & \multicolumn{1}{c}{ RT-PCR } & Consistency (\%) \\
\hline Tuber & 120 & 83 (positive) & 84 (positive) & $116 / 120(96.7)$ \\
Leaf & 120 & 91 (positive) & 89 (positive) & $118 / 120(98.3)$ \\
Total & 240 & 174 (positive) & 173 (positive) & $234 / 240(97.5)$ \\
\hline
\end{tabular}

a One-step RT-LAMP-turbidity analysis using primers FIP, BIP, F3 and B3. Samples were considered positive when the absorbance readings at $405 \mathrm{~nm}$ were greater than three times the means of negative controls.

${ }^{\mathrm{b}}$ Results of individual samples diagnosed by RT-PCR and RT-LAMP were compared. a more sophisticated thermocycler $(4,5)$. Also, because no gel electrophoresis is required for visualization of positive reactions in RT-LAMP assays, staining of the gel involving hazardous compounds such as ethidium bromide is avoided.

Accurate and efficient diagnosis of PVY from potato tubers is often challenging due to low virus titer in dormant tubers (17). For detection of the virus using ELISA, sprouting tubers are required (17). Although RT-PCR can detect PVY effectively from most dormant tubers, underdetection of tubers that contain the virus occurs $(10,17)$. In this study, both RT-PCR and RT-LAMP detected fewer positives from tubers than from leaf samples. In addition to low concentration of the virus in tuber samples, other factors such as uneven distributions of PVY within tuber tissues (17) also might have contributed to the apparent underdetection of the positives by both methods.

Some discrepancies (3.3 and $1.7 \%$ in tuber and leaf samples, respectively) occurred between the results of RT-PCR and RT-LAMP assays. The accuracy and efficiency of RT-PCR in potato virus detection and strain differentiation has been demonstrated in many studies $(10,11,15)$; therefore, the technique could be considered a standard reference method for RT-LAMP. The discrepancies between the two methods may indicate that further optimization and evaluation of RT-LAMP using a large number of samples from various plant tissues are needed.

In conclusion, with results comparable with the two-step RT-PCR assay in potato leaf and tuber samples, the one-step RTLAMP-turbidity analysis exhibited excellent potential for the detection of PVY in both research and diagnostic labs, and offers a sensitive and efficient alternative for diagnosis of the virus.

\section{ACKNOWLEDGMENTS}

I thank K. Corey and T. Molen for technical assistance, M. Singh for assistance in using Microplate Reader, and $\mathrm{H}$. Tai and R. King for critically reading the manuscript.

\section{LITERATURE CITED}

1. Ahloowalia, B. S. 2001. Potato from famine to global food security. ABN 073 AgBiotechNet $3: 1-7$

2. Clark, M. F., and Adams, A. N. 1977. Characteristics of the micro-plate method of enzymelinked immunosorbent assay for the detection of plant viruses. J. Gen. Virol. 34:475-483.

3. Fukuta, S., Iida, T., Mizukami, Y., Ishida, A., Ueda, J., Kanbe, M., and Ishimoto, Y. 2003. Detection of Japanese yam mosaic virus by RT-LAMP. Arch. Virol. 148:1713-1720.

4. Hadidi, A., Levy, L., and Podleckis, E. V. 1995. Polymerase chain reaction technology in plant pathology. In: Molecular Methods in Plant Pathology. R. P. Singh and U. S. Singh, eds. CRC Press, Boca Raton, FL.

5. Henson, J. M., and French, R. 1993. The polymerase chain reaction and plant disease diagnosis. Annu. Rev. Phytopathol. 31:81-109.

6. Holmes, F. O. 1929. Local lesions in tobacco mosaic. Bot. Gaz. 87:39-55.

7. Iwamoto, T., Sonobe, T., and Hayashi, K. 
2003. Loop-mediated isothermal amplification for direct detection of Mycobacterium tuberculosis complex, M. avium, and M. intracellulare in sputum samples. J. Clin. Microbiol. 41:2616-2622.

8. Mori, Y., Nagamine, K. Tomita, N., and Notomi, T. 2001. Detection of loop mediated isothermal amplification reaction by turbidity derived from magnesium pyrophosphate formation. Biochem. Biophys. Res. Commun. 289:150-154.

9. Nagamine, K., Hase, T., and Notomi, T. 2002. Accelerated reaction by loop mediated isothermal amplification using loop primers. Mol. Cell. Probes 16:223-229.

10. Nie, X., and Singh, R. P. 2001. A novel usage of random primers for multiplex RT-PCR detection of virus and viroid in aphids, leaves, and tubers. J. Virol. Methods 91:37-49.
11. Nie, X., and Singh, R. P. 2002. A new approach for the simultaneous differentiation of biological and geographical strains of Potato virus $Y$ by uniplex and multiplex RT-PCR. J. Virol. Methods 104:41-54.

12. Nie, X., Singh, R. P., and Singh, M. 2004. Molecular and pathological characterization of $\mathrm{N}: \mathrm{O}$ isolates of the Potato virus $Y$ from Manitoba, Canada. Can. J. Plant Pathol. 26:573-583.

13. Notomi, T., Okayama, H., Masubuchi, H., Yonekawa, T., Watanabe, K., Amino, N., and Hase, T. 2000. Loop-mediated isothermal amplification of DNA. Nucleic Acids Res. 28:e63.

14. Parida, M., Posadas, G., Inoue, S., Hasebe, F., and Morita, K. 2004. Real-time reverse transcription loop-mediated isothermal amplification for rapid detection of West Nile virus. J. Clin. Microbiol. 42:257-263.

15. Singh, M., and Singh, R. P. 1996. Factors affecting detection of PVY in dormant tubers by reverse transcription polymerase chain reaction and nucleic acid spot hybridization. J. Virol. Methods 60:47-57.

16. Singh, R. P., McLaren, D. L., Nie, X., and Singh, M. 2003. Possible escape of a recombinant isolate of Potato virus $Y$ by serological in dexing and methods of its detection. Plant Dis. 87:679-685.

17. Singh, R. P., Nie, X., and Singh, M. 2000 Duplex RT-PCR: reagent concentrations at reverse transcription stage affect the PCR performance. J. Virol. Methods 86:121-129.

18. Slack, S. A., and Singh, R. P. 1998. Control of viruses affecting potatoes through seed potato certification programs. Pages 249-260 in: Plant Virus Disease Control. A. Hadidi, R. K. Khetarpal, and H. Koganezawa, eds. American Phytopathological Society Press, St. Paul, MN. 